\title{
WHAT DO THE YOUTH KNOW ABOUT ALTERNATIVE ENERGY SOURCES - CASE STUDY FROM HUNGARY AND SLOVAKIA'
}

\section{Katalin Takács-György ${ }^{1 *}$, Szilvia Domán', Antalné Tamus ${ }^{1}$, Elena Horská2, Zuzana Palková2}

\author{
'Károly Róbert College, Hungary \\ ${ }^{2}$ Slovak University of Agriculture in Nitra, Slovak Republic
}

\begin{abstract}
Wider use of alternative energy sources is a real requirement of sustainable economy - not only from the point of view of limited natural resources -, and there is a question what is the knowledge, the attitude of young generation. As there is a strong connection between the use of renewable energy and sustainability, the issues must be examined together. On the other hand it can be observed that there is a tendency that people are becoming more open and inquiring towards renewable energy sources, and environment protection is considered as a very important task. The main goals of the research were to examine the knowledge of the young generation taking part in higher education on sustainability and alternative energy, and to find out their attitudes to the use of different alternative energy sources. Also, our hypotheses said that the level of knowledge of sustainability and their attitudes to the environment issues are connected. We compared the results of two surveys carried out in 2014 among the students of a Hungarian and a Slovak higher educational institute. According to the primary results it can be stated that the increasing environmental awareness of young generation is visible, although as for the concepts of sustainability and their knowledge on alternative energy sources, as well as their expectations for the future, there was no significant correlation between their opinions in the Hungarian sample. It was proved that they have open minds towards environmental consciousness, and follow the renewable energy sources with attention. A bit more than a half of the sample has real knowledge on sustainability - we mean the three-pillars model here - , more the mail interview has higher knowledge and for the future they thought the question as a very important one. Considerable majority of the respondents, compared to their capabilities, try to live environmentally-sound life, will do more than one thing to save their environment, although also some negative responses slightly appeared in the received results. Primary results of the Slovak sample are similar; respondents do similar measures for environment at their households as their Hungarian colleagues, but with different priority. Concerning the knowledge of concept of "green economy", "blue economy" and the "non-growth", it can be summarized that the awareness is evident but in many cases, there is just few information and weak knowledge connected with the terminology and practical consequences. We think it is an important task of education to increase the awareness of young people on sustainable energy use and to let them accustomed to the thought of green economy and non-growth theories, since the expansion of knowledge may help in the development of a more positive attitude, which will then, hopefully, encourage their actions in the future.
\end{abstract}

Keywords: renewable energy, survey, knowledge, young generation

\section{Introduction}

It is a question concerning the renewable energy, what is the knowledge, the attitude of young generation on it, can we - and if yes - how can we improve their knowledge and make them conscious consumers. All these thoughts are in strong connection with sustainability and sustainable development. The definition of sustainability of environment comes from the Burtland Report (1987). According to Pearce and Atkinson's (1995) understanding, natural resources and man-made capital are complementary to each other in the production process, so that natural resources create the limiting factors to increase production, and at the same time, they should be used rationally during the production. Here comes the question of renewable energy into the discussion. By the turn of the millennium, sustainability has a broader interpretation. Sustainability - from wider aspect - has three main focus areas - environmental, economic and social ones. The term "sustainable development" includes the current and long-run sustainable production and the controversies of environmental protection that assure the right quality of life, and hard-preventable, but rather tolerated conflicts. In the realization of serious regional, national, social (and of course, political) interests, current, short and long-run visions clash, they are often contradictory (Chilinsky, 1998; Berndes et al., 2003; Behnassi et al., 2011; Turek, 2013; Valkó et al., 2013; Popp et al., 2014).
Share of renewable energy in gross final energy consumption in the European Union differs by countries; the highest one is in Sweden $152.5 \%$ in 2012) and the lowest one in Malta (0.2\%).

The EU has been making progress towards meeting the 2020 target of $20 \%$ renewable energy in gross final energy consumption. In 2010, the share of renewable energy in the EU was $12.7 \%$ compared to $8.5 \%$ in 2005 . One of the important challenges is to ensure over time that renewable energy sources become more cost-efficient and get more costumed the consumers to the use of renewable energy.

Nowadays the renewable energy sources phrase is a widely used term in the issue of sustainable development. This kind of energy sources gains energy from the Sun, wind, water, and plants. Several studies were carried out on alternative energy sources, usage and the consumers' attitudes both in Hungary and in Slovakia. All of them highlighted the lack of real knowledge, the role of education of youth (Fogarassy et al., 2009; Jobbágy and Bai, 2012; Balogh et al., 2015).

The use of renewable energy cannot be separated from sustainability (Smalley, 2003). The environmental and social sustainability criteria in line with economic development will be qualified the top priority in the EU's budgetary period 2014-2020 (ECD, 2013). Not going deeply into the question of the newer concepts, models, such as green economy, blue economy, and the non-growth are published with regard to sustainability. The

\footnotetext{
1 The paper is based mainly on the book: Palkova, Z. - Horska, E. - Gadus, J. - Massari, S.F. - Domán, Sz. - Takács-György, K. 2015. Renewable Energy in Europe: Through the Policy, Education and People. Szent István Publishing House, Gödöllö. 164 p.
} 
background of green economy model functions is that investors have to accept a lower return on investment, and the consumers will have to pay more. According to the concept of Blue Economy, the base of innovations is the use of nutrients and energy that use the power of nature (Pauli, 2011; Tóth, 2012). The question of renewable energy is also highlighted here. The principle of non-growth is primarily aimed the decrease of the environment overload production and overconsumption without the decrease of individual welfare (Latouche, 2011; Szabó and Takácsné, 2001). Also, the conflict of land use concerning the energy production coming from primer biomass must be mentioned. The expansion of bioenergy makes effects on the produced food, on the food price, strengthens the competition between the countries, the antagonism between
North and South (Farkas-Fekete et al., 2011; Popp et al., 2014). All of these models specifically address the issue of power generation, non-fossil energy sources. It is also important to mention the necessity of holistic thinking. Not only the production of alternative energy must be taken into consideration, but the whole embodied energy need (Takács et al., 2012).

Until renewable energy sources become cost-competitive, the objective of a more sustainable energy system must go hand in hand with the need for a fully liberalized and integrated energy market capable of mobilizing and allocating investment efficiently and a hard change in consumers' minds and attitudes. In this paper we did not want to deal with the question of cost-efficiency and the role of subsidies, only the consumers' attitudes were in our focus.

Table 1 Share of renewable energy in gross final energy consumptio

\begin{tabular}{|c|c|c|c|}
\hline Country & 2011 in \% & 2012 in \% & Indicative trajectory $2011 / 2012$ in \% \\
\hline Sweden & 49.4 & 52.4 & 41.6 \\
\hline Finland & 32.8 & 34.4 & 30.4 \\
\hline Latvia & 32.7 & 33.0 & 34.1 \\
\hline Austria & 30.7 & 31.9 & 25.4 \\
\hline Estonia & 25.9 & 27.8 & 19.4 \\
\hline Denmark & 23.7 & 26.3 & 19.6 \\
\hline Portugal & 25.0 & 24.7 & 22.6 \\
\hline Romania & 21.3 & 21.3 & 19 \\
\hline Lithuania & 20.3 & 20.8 & 16.6 \\
\hline Slovenia & 19.8 & 20.6 & 17.8 \\
\hline Bulgaria & 14.1 & 17.9 & 10.7 \\
\hline Spain & 13.2 & 14.2 & 11.0 \\
\hline France & 11.3 & 13.7 & 12.8 \\
\hline Italy & 12.2 & 13.5 & 7.6 \\
\hline Greece & 10.9 & 12.5 & 9.1 \\
\hline Germany & 11.6 & 12.3 & 8.2 \\
\hline Czech Republic & 9.4 & 11.3 & 7.5 \\
\hline Poland & 10.4 & 11.1 & 8.8 \\
\hline Slovakia & 9.9 & 10.6 & 8.2 \\
\hline Hungary & 9.1 & 9.8 & 6.0 \\
\hline Ireland & 6.6 & 7.5 & 5.7 \\
\hline Cyprus & 5.4 & 7.0 & 4.9 \\
\hline Belgium & 5.2 & 6.8 & 4.4 \\
\hline Netherlands & 4.4 & 4.5 & 4.7 \\
\hline United Kingdom & 3.8 & 4.2 & 4.0 \\
\hline Luxemburg & 2.9 & 3.1 & 2.9 \\
\hline Malta & 0.2 & 0.3 & 2.0 \\
\hline Total EU & 12.9 & 14.0 & - \\
\hline
\end{tabular}

During the last two decades, the population has become more open and inquiring towards renewable energy sources in the former postsocialist countries. In Hungary, it was found out in earlier researches that there is a changing attitude to renewable energy, more people know its types and can mention them (Dinya et al., 2006; Kórik, 2014; Domán et al., 2015). According to a recent research, $90 \%$ of the people in Hungary clearly support the greater use of renewable energies (Anonymous, 2011).

In connection with the topic, the next generation's attitudes should be clearly discovered, because they will be not only the beneficiaries of the present decisions, or even the endure. Becoming individual consumers, they will have huge impact on the future's tendencies. The young people consider the environment protection as a very important task and take a little bit more efforts than medium to preserve the world around them. There is a relationship between environmental attitudes of young generation and their environmental knowledge. More environmental knowledge brings more positive environmental attitudes.

In this study, we compared results of two primary researches with regard to environmental consciousness within young adults, in which light is thrown on the age-group expertness in the topic, their attitude, and the results can be comparable with previous studies' tendencies carried out in a wider sample of age in Hungary and in Slovakia. A part of the results was published as a chapter of Renewable Energy in Europe (2015).

The aim of our primary researches was to assess and to compare the youth (age-group 18-35 years) knowledge and attitudes with regard to sustainable development and renewable energy sources in Hungary and Slovakia.

Our hypotheses were the following:

H1: The residents have open minds towards environmental consciousness, and follow the renewable energy sources with attention.

H2: Support for the establishment of an alternative energy production plant in a settlement where they live would primarily be expressed only if the investment does not cost them anything.

\section{Material and methods}

The research has revealed the level of knowledge of renewable energy and environmental sustainability influencing the approach to the environment. We also touch upon the alternative energies, the issues of expectations for its use 
and the attitudes to their usage. It was also examined how the young adults are concerned with the environmental consciousness, how it penetrates their lives and what kind of activities they are willing to take in order to protect their environment. This can be basically considered as a comparison of theory and its implementation.

The research was carried out in FebruaryMarch 2014 among the students in Hungary Károly Róbert College's full-time, part-time and distance education students in Gyöngyös and in Slovakia - among the students at the Slovak University of Agriculture, but in a wider public as well.

The number of interviewed people was 400 in the Hungarian sample, 304 were included in the evaluation. As many as 300 people were interviewied in the Slovak sample, the number of respondents was 360 . The sampling was not a representative one, it was an arbitrary one, in addition we aspire that the sample showed more varied picture regarding the demographic characteristics.

As the two surveys were not exatly the same (concerning the number of respondents and típe and the different number of the habitants), the results must be extrapolated with reservations.

We chose the young generation and within it, people with higher education, because we think that they are open-minded, sensitive to the questions of environmental protection, they are more environmentally conscious. From other aspect they will become "determinative leaders" of their generation.

During the research, a non-representative, arbitrary sampling was used, and regarding the respondents' demographic characteristics the sample showed more varied picture. The sample size: 400 people.

\section{Results and discussion}

During the interviews in Hungary, females are over-represented compared to the statistical average, $73.2 \%$. The participatns from Slovakia were more equally distributed- $49 \%$ males and $51 \%$ females. From the age point of view, in Hungary $17.0-18.4 \%$ of the respondents were under 25 and over 40, nearly two-thirds of the respondents were from the age group of 26-40 years. In Slovakia, $48 \%$ were younger than 25 years, $4 \%$ older than 40 and $47 \%$ between $25-40$ years.

Because the interviews were hold among students in Hungary, it is not surprising that the decisive majority of respondents have completed the secondary education (82.4\%) and $16.9 \%$ of respondents have a college degree. Two people in

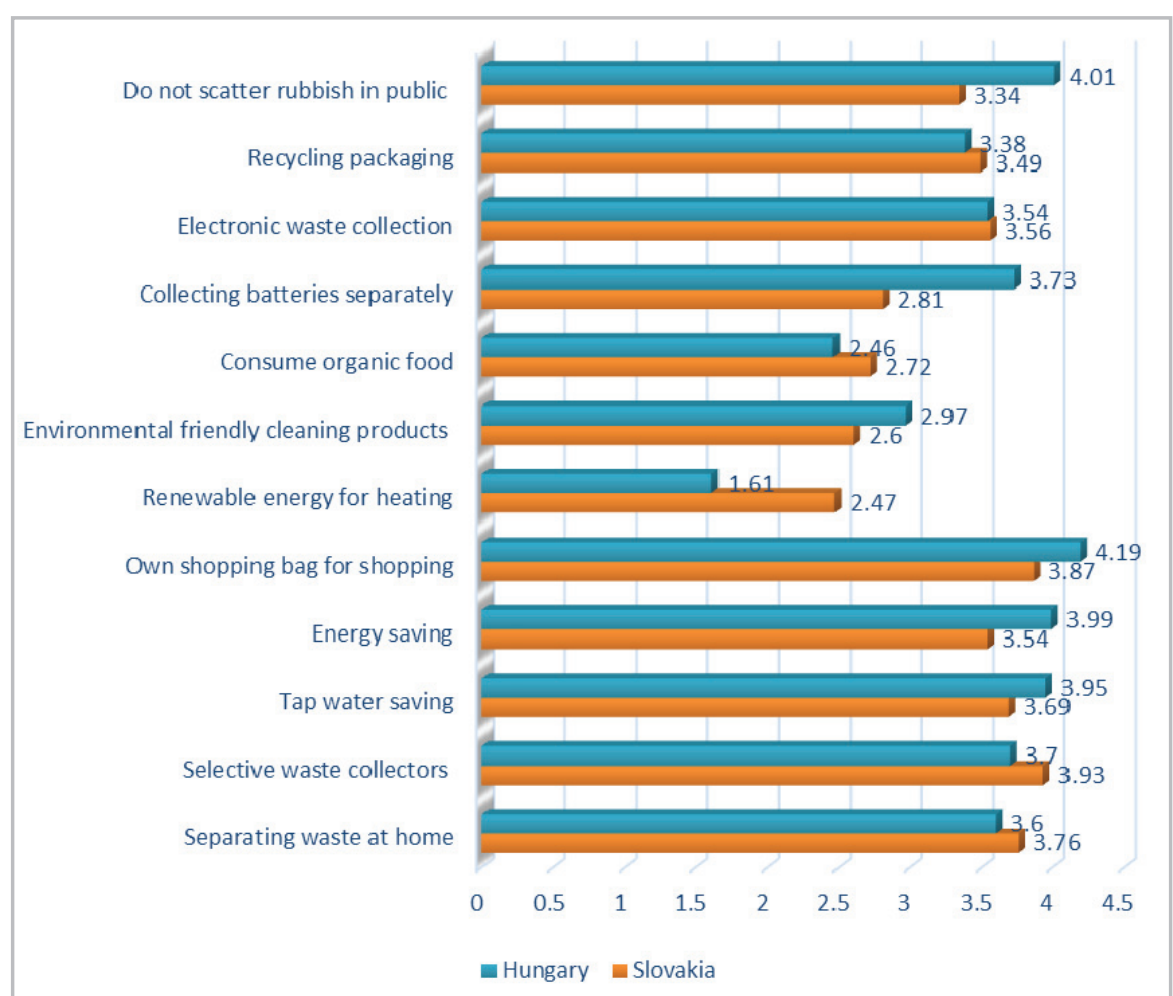

Figure 1 Activities for the interest of environment care in Hungary and in Slovakia

the sample had primary education, due to the fact that the survey was filled out with accompanying people who arrived with our students. In Slovakia, because of including public, the situation was a little bit different $-51.6 \%$ of respondents have completed secondary education, $47.3 \%$ graduated at the university and $1.1 \%$ had only elementary education.

A little more than three quarters of the sample were active employees in Hungary. Among the respondents, $15.9 \%$ were "professional" students, $5.8 \%$ learn in addition to maternity care fee and 2.2\% were unemployed. In Slovakia, $89.1 \%$ were students, $8.7 \%$ active employees and $2.2 \%$ were on maternity.

\section{Environmental consciousness}

Evaluating the responses about environment care lifestyle, the following can be stated. In Hungary, only $6 \%$ of respondents declared that "I'm fighting for the environment protection with all my might, I'm environmentally conscious". In Slovakia, it was $11.2 \%$ of respondents.

The considerable majority of respondents (69.3\% in Hungary and $65.2 \%$ in Slovakia) according to their admission try to live environmentally friendly, in accordance with their capabilities. The total of $20 \%$ in Hungary and $11.2 \%$ in Slovakia will do more things for environment care, $4 \%$ of Hungarians and $20.2 \%$ from Slovakia are concerned about the topic, but there is no (financial or other) possibility to act.
The negative responses slightly appeared in the obtained results, so $0.7 \%$ (Hungary) and $1.1 \%$ (Slovakia) had heard about it but did not care and no one chose "No, I do not know what constitutes the term" category from among the listed options.

H1: The residents have open minds towards environmental consciousness, and follow the renewable energy sources with attention.

Though the young generation knows about sustainability, they are keen on environment protection, majority of the respondents try to live environmentally friendly, but the level depends on their financial background, so the first assumption was not proved.

We interviewed them on the question what the respondents do for care for the environment (households). Measuring the respondents' opinions we used a Likert scale ranging from 1 to 5 , where 1 is "never" and 5 represents "always" value (Figure 1).

In Hungary, the highest values were given for the following features "I bring my own shopping bag for shopping (4.1\%)" and "I do not scatter rubbish in public (4.01\%)". Close behind in the rank there is situated energy (3.99\%) and tap water (3.95\%) saving.

Close to the value 4 there is represented collecting batteries separately (3.73) and use of the selective waste collectors (3.7) category.

The least typical of the respondents is the use of renewable energy for heating (1.61), 


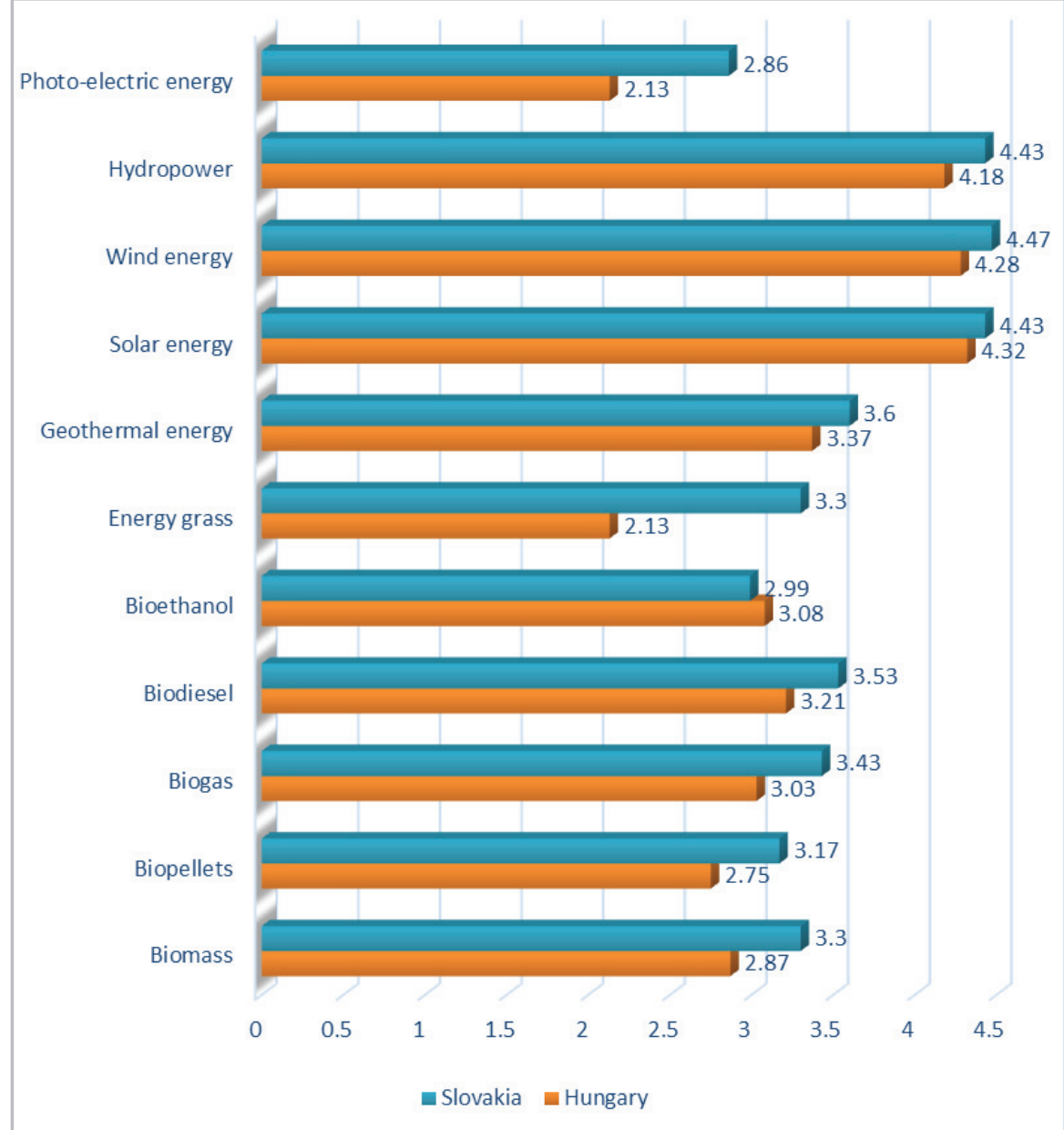

Figure 2 What comes to your mind when renewable energy sources are in question?

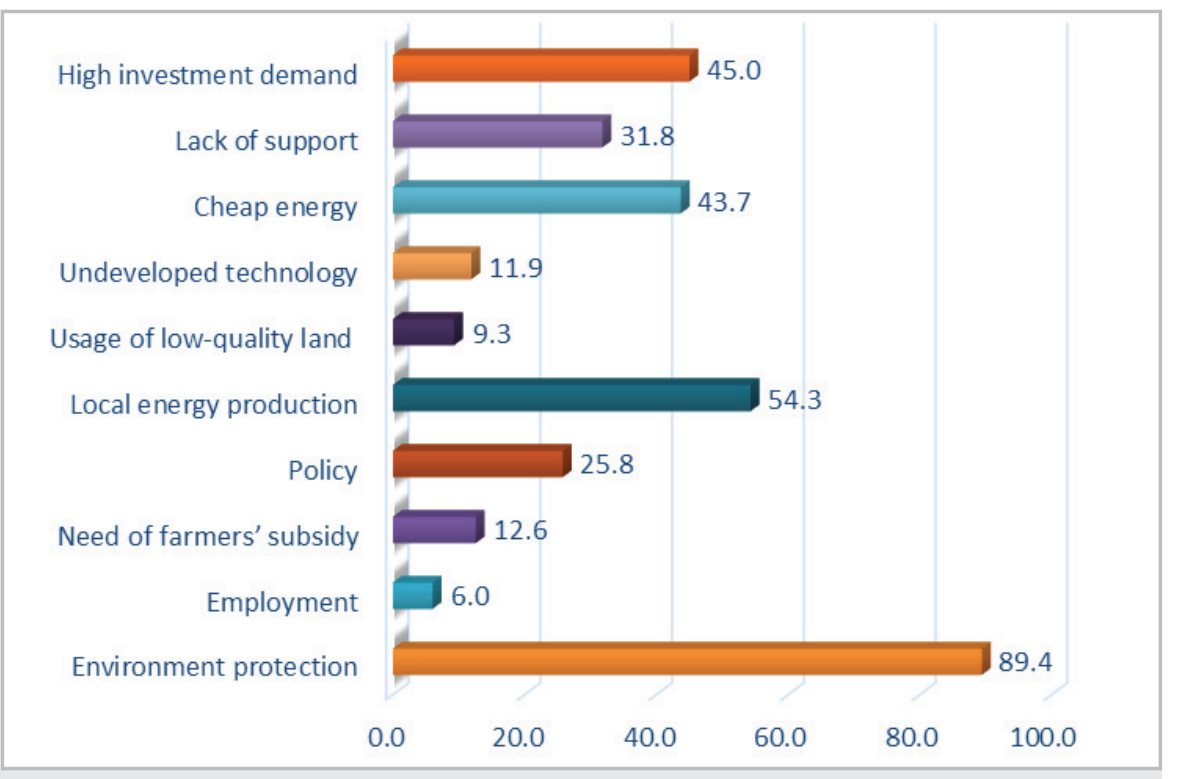

Figure 3 Association for renewable energy sources Hungary in \%

consuming organic food (2.46) and the use of environmentally friendly cleaning products (2.97).

Situation in Slovakia is a little bit different - the highest ranked activity was Selective waste collectors 3.93, followed by Own shopping bags (3.87) and Separating waste at home 3.76. The lowest marks were

\section{Renewable energy sources}

To examine the knowledge on renewable energy, the respondents got a list and they had to mark what they know. Most of the respondents at first identified the characteristics of traditional renewable energies like wind, solar and water energy (Figure 2).

The issues of the energy plants, biopellets and biomass were the least recognizable ones.

The more knowledge on renewable energy resources is recorded by the interviewed young respondents in Slovakia. Later on, we found out they are more enthusiastic with environment protection.

Examining the awareness on renewable energy sources, we stated the following, take $100 \%$ a full range awareness of renewable energy as shown Figure 3.

Among the interviewed Hungarian young people, solar energy $(86.4 \%)$, wind energy (85.6\%), hydropower (83.6\%) and geothermal energy (67.4\%) attained the highest awareness (index). The least known are photo-electric energy (42.6\%), energy grass (42.6\%), energy forest $(44.4 \%)$, pellets $(55 \%)$ and biomass (57.4\%).

We also looked for answers in our questionnaire about how the youth age-group judges the future of various renewable energy sources.

Studying the support for energy plant establishment creating renewable energy carried out in a settlement, the respondents in both countries would primarily support this type of investment if it does not cost them anything.

We can state as a fact the offer of their own work is more than one third $-36.8 \%$ in Hungary and $32.14 \%$ in Slovakia -, however, the willingness of financial supportis small $13.9 \%$ in Hungary and $8.33 \%$ in Slovakia (Figure 4).

In the issue of renewable energy sources use in the respondent's household, we examined whether the respondents used or would use renewable energy in their own households. Based on the results, it can be stated that the majority of respondents would use the new alternative sources of energy in case of any condition met. The total of $47.2 \%$ (Hungary) and $32.22 \%$ (Slovakia) indicated "I would use, if I got subsidy", 43.1\% (Hungary) and $24.44 \%$ (Slovakia) said "I would use if it was cheaper than the current energy carriers" and $38.9 \%$ in Hungary and $18.89 \%$ in Slovakia said that they would use if the investment quickly returned. Only $1.4 \%$ of Hungarian, but $13.3 \%$ of respondents from Slovakia indicated the 


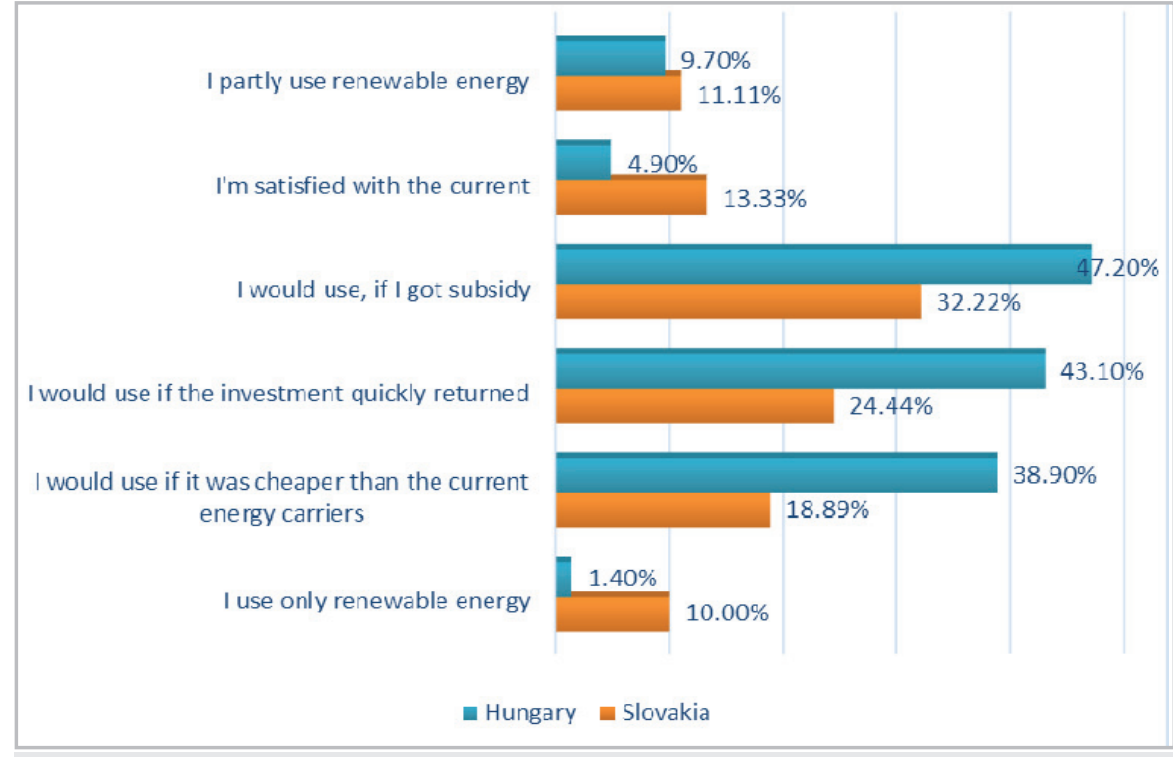

Figure 4 The use of renewable energy sources in the respondent's household

following answers: "Yes, I use only renewable energy". In Hungary, $9.7 \%$ and $11.11 \%$ of respondents in Slovakia use partly renewable energy.

In our research we also examined what opinion do young people have about a potentially established renewable energy plant. According to the significant majority, $84 \%$ and $63.82 \%$ of the respondents would be beneficial from a point of environmental protection view, for the establishment of a renewable energy plant in their settlement, according to $62.5 \%$ and $22.37 \%$ of them it will have a financial advantage for the establishment of such a type of plant. Only a few respondents (2.1\% and $5.26 \%$ ) said that it would be disadvantageous for them and none from Hungary and 5.92\% from Slovakia thought a disadvantage would come from such an investment for the residence.

H2: Support for the establishment of an alternative energy production plant in a settlement where they live would primarily be supported only if the investment does not cost them anything.

Our second assumption was proved; their plans for investment into renewable energy use in settlement level and in their personal lives depend on the potential subsidy systems.

\section{Conclusions}

On the basis of the results it can be stated that we proved that the residents have open minds towards environmental consciousness, and follow renewable energy sources with attention both in Hungary and in Slovakia. It must be highlighted here that the research was not representative for the whole young generation. The results are true for higher level educated youth, living mainly in rural areas and in smaller towns, closer to the environment.

Considerable majority of the respondents, with respect to their capabilities, try to live environmentally-sound lives, will do more than one thing to save their environment, the negative responses seldom appearing on the received results.

The respondents have interests in environment (household) welfare, use shopping bags, do not scatter rubbish in public area, and save on tap water and electricity. The respondents are the least characterized as a consumers' of use of environmental friendly cleaning products and the use of renewable energy for heating. However, we believe that the latter result does not mean that alternative energy sources have not been the focus of the public interest, but rather their high investment costs and the lack of available subsidies (see: below) retain many from the modifications.

Concerning the renewable energy resources, most of respondents associated with environment protection, local and cheap energy production and the high investment demand.

Studying the support for the establishment of an alternative energy production plant on a settlement it can be observed that the respondents would primarily support this type of investment if it does not cost them anything. Analyzing the use of renewable energy sources within the respondent's household indicates that the majority of the survey participants would apply the new alternative energy sources in case some conditions will be met, state subsidy, low costs, rapid return on investment. According to the significant majority of respondents, the creation of a renewable energy plant in their settlement would be beneficial from the environmental point of view and would result in financial advantages from establishment of this type of plants.

The results support the assertion that in the life and everyday life of young people, protecting the environment has been an important factor. In our opinion it is very important to extend their knowledge on renewable energy sources, concerning the sustainable development. Expansion of experiences and knowledge can help in coming into existing positive attitude expected to appear in their behaviour and doings in the future (not too far). There is a following need from our research results: to devote attention to newly developed concepts (both fundamental and applied) related to environmental and bioenergetic studies. Ongoing global change is a complex issue integrating natural and social sciences, climate and energy policy debates. The modern industrial economy has to ensure energy security, economic development, considering environmental aspects and perception of all generations.

\section{Acknowledgement}

The paper was supported by the TÁMOP4.2.2.D-15/1/KONV - 2015-0010 project.

The research leading to these results received funding from the European Community under project no. 26220220180: Building Research Centre "AgroBioTech."

\section{References}

ANONYMUS (n.a.). 2013. Megújuló energiaforrások. A müszaki szakportál. Beküldő : Dashöfer Szakkiadó. Letöltve: 2013. 04. 13. http://www.muszakiak.hu/ tudastar/energia/megujulo-energiaforrasok

BALOGH, P. - BAI, A. - POPP, J. - HUZSVAI, L. - JOBBÁGY, P. 2015. Internet-orientated Hungarian car drivers' knowledge and attitudes towards biofuels. In Renewable and Sustainable Energy Reviews, 2015, no. 48, pp. $17-26$.

BEHNASSI, M. - SHAHID, S. A. - D'SILVA, J. (Eds.) 2011. Sustainable Agricultural Development. Recent Approaches in Resources Management and Environmentally-Balanced Production Enhancement. Springer. p. 278.

BERNDES, G. - HOOGWIJK, M. - VAN DEN BROEK, R. 2003. The contribution of biomass in the future global energy supply: a review of 17 studies Biomass and Bioenergy, 25. pp. 1-28.

CHILINSKY, G. - HEAL, G. - VERCELLI, A. 1998. Sustainability: Dynamics and Uncertainity. Kluwe Academic Publication. Drodrecht - Boston - London. $249 \mathrm{p}$. 
DINYA, L. - DOMÁN, SZ. - FODOR, M. - TAMUS, A-NÉ. 2006. Az alternatív energiaforrások lakossági megítélése. In Marketing \& Menedzsment, vol. 40, 2006, no. 4, pp. 49-55.

EUROPEAN COMMISSION'S DIRECTORATES. 2013. Common Guidance on Community Led Local Development. http://enrd.ec.europa.eu/themes/clld/, letöltve: 2013.05.31., 62. p.

FEKETE FARKAS, M. - VALKÓ, G. - TÓTH, R. 2011. Global challenges and biofuels. In International Journal of Social Sciences and Humanity Studies, vol. 3, 2011, no. 1, pp. 1309-8063.

FOGARASSY, CS. - GÉMESI, ZS. - LUKÁCS, Á. 2009. Professional and training needs in the area of hybrid power system - Alternative energy conditions overview in Hungary to identify the vocational training priorities and information content levels. In Hungarian Agricultural Engineering, 2009, no. 22, p. 34.

JOBBÁGY, P. - BAI, A. 2012. The effects of the global economic crisis on the markets for fossil and renewable fuels. In APSTRACT - Applied Studies in Agribusiness and Commerce, vol. 6, 2012, no. 3-4, pp. 131-136.

KÓRIK, K. 2014. Gazdaság és fenntartható fejlődés: a svéd és a magyar helyzet összehasonlító elemzése. In Journal of Central European Green Innovation, vol. 2, 2014, no. 1, pp. 91-111.

LATOUCHE, S. 2011. A Nemnövekedés diszkrét bája. Savaria University Press, 2011. 138 p.

PALKOVÁ, Z. - HORSKÁ, E. - GADUŠ J. - MASSARI, S.F. - DOMÁN, SZ. - TAKÁCSGYÖRGY, K. 2015. Renewable Energy in Europe: Through the Policy, Education and People. Szent István Publishing House : Gödöllő, 2015. 164 p.

PAULI, G. 2011. A Kék Gazdaság - 10 év - 100 innováció - 100 millió munkahely. Kiadó : PTE KTK, 2011, $372 \mathrm{p}$.

PEARCE, D. - ATKINSON, G. 1995. Measuring of sustainable development. In Bromly, D. ed.: Tha Handbook of Environmental Economics, 1995. pp. 166-181.

POPP, J. - LAKNER, Z. - HARANGI-RÁKOS, M. - FÁRI, M. 2014. The effect of bioenergy expansion: Food, energy, and environment. In Renewable and Sustainable Energy Review, 2014, no. 32, pp. 559-578.

SMALLEY, R. E. 2003. Top Ten Problems of Humanity for Next 50 Years. In Energy \& Nano Technology Conference, Rice University, May 3, 2003. 16 p.
SCHMITZ, C. - van MEIJL, H. - KYLE, P. - NELSON, G. - FUJIMORI, S. - GURGEL, A. HAVLIK, P. - HEYHOE, E. - D'CROZ, D.M. - POPP, A. - SANDS, R. - TABEAU, A. - van der MENSBRUGGHE, D. - von LAMPE, M. - WISE, M. - BLANC, E. - HASEGAWA, T. KAVALLARI, A. - VALIN, H. 2013. Land-use change trajectories up to 2050: insights from a global agro-economic model comparison. Agric Econ, 2013. http://dx.doi. org/10.1111/agec.12090 (Downloaded: 22 May, 2015).

SZABÓ, A. K. - TAKÁCSNÉ, Gy. K: 2011. A nemnövekedés segíthet legyózni az energiaválságot? In Acta Karolus Robertus, vol. 1, 2011, no. 2, pp. 140-152.

TAKÁCS, I. - NAGY-KOVÁCS, E. - HOLLÓ, E. - MARSELEK, S. 2012. Model for optimization of biomass utilization for energy production by energetic and economic requirements. In Review of Applied Socio-Economic Research, vol. 4, 2012, no. 2, pp. 225-235.

TÓTH, G. 2012. A fenntarthatóság gazdasági paradigmája felé "Gazdaság és morál: tiszta társadalom, tiszta gazdaság" Kautz Gyula Emlékkonferencia. 2012. június 12. elektronikus formában megjelenő Kötete: http://kgk.sze.hu/konferenciakotet.2012.

TUREK, R. A. 2013. Sustainable Technologies, Policies and Constraints in the Green Economy - Sustainable agriculture - between sustainable development and economic competitiveness. IGI Global Publishing, pp. 219-223.

VALKó, G. - TÓTH, R. - VINOGRADOV, SZ. - FEKETE-FARKAS, M. 2013. Measurement of Sustainability of Agriculture. In Vadyba, vol. 23, 2013, no. 2, pp. 141-148.

WORLD COMMISSION ON ENVIRONMENT AND DEVELOPMENT (WCED). 1987. Burtland Report. New York : United Nations.

\section{Contact addresses}

Katalin Takács-György, professor, Károly Róbert College, Hungary, 3200 Gyöngyös, Mátrai u. 36, e-mail: tgyk@karolyrobert.hu 